\title{
Trophic consequences of an invasive, small-bodied non- native fish, sunbleak Leucaspius delineatus, for native pond fishes
}

\author{
Tea Bašić • Gordon H. Copp • V. Ronni Edmonds-Brown • Emre Keskin • \\ Phillip I. Davison · J. Robert Britton
}

Received: 23 January 2018/ Accepted: 19 August 2018/Published online: 27 November 2018

(C) Crown 2018

\begin{abstract}
Assessments of the trophic consequences of invasive fishes are important for quantifying their ecological impacts on native species more generally. A small-bodied cyprinid fish native to continental Europe and introduced in the 1970s to the U.K, the sunbleak Leuciscus delineatus, has been shown previously to establish closer social associations with native species of similar size than do native species amongst themselves. To assess the potential detrimental trophic consequences of native species associations with $L$. delineatus, a field-based experiment
\end{abstract}

T. Bašić · G. H. Copp ( $\varangle)$ · E. Keskin · P. I. Davison Centre for Environment, Fisheries and Aquaculture Science, Salmon and Freshwater Team, Pakefield Road, Lowestoft NR33 0HT, UK

e-mail: gordon.copp@cefas.co.uk

G. H. Copp · P. I. Davison · J. R. Britton

Centre for Conservation and Environmental Change,

School of Conservation Sciences, Bournemouth

University, Poole, Dorset BH12 5BB, UK

G. H. Copp

Environmental and Life Sciences Graduate Program,

Trent University, Peterborough, ON K9J 7B8, Canada

V. R. Edmonds-Brown

University of Hertfordshire, College Lane, Hatfield,

Hertfordshire AL10 9AB, UK

E. Keskin

Evolutionary Genetics Laboratory (eGL), Department of Fisheries and Aquaculture, Faculty of Agriculture, Ankara University, Diskapi, 06110 Ankara, Turkey was undertaken in summer 2015 in six outdoor, artificial ponds containing three native cyprinid species (rudd Scardinius erthrophthalamus, gudgeon Gobio gobio, tench Tinca tinca). Three ponds were controls (no L. delineatus) and three were treatments ( $L$. delineatus present). The results of stable isotope analysis (SIA) of fish tissue samples provided strong evidence that the isotopic niches of both native benthic fishes were reduced in the presence of $L$. delineatus, although there were no significant effects on the trophic position, body size or condition of two of the three native fish species. Introduced $L$. delineatus maintained a core isotopic niche that was distinct from the two native benthic fishes, with no overlap detected between native and non-native fishes when including $40 \%$ and $95 \%$ of the data. These results indicate that the response of the native fishes to the introduction of L. delineatus was niche constriction via trophic specialisation, with this response sufficient to maintain their growth rates and condition. This result is similar to studies on a range of small-bodied invasive fishes, suggesting the trophic impacts of these invaders are relatively consistent across species and systems.

Keywords Trophic niche - Stable isotope analysis . Non-native species · Niche constriction · Outdoor experimental ponds 


\section{Introduction}

There is a plethora of research suggesting non-native freshwater fishes cause adverse ecological impacts on native species and ecosystems (e.g. Collier et al. 2017; Klop-Toker et al. 2017). However, with the exception of certain species, e.g. common carp Cyprinus carpio (e.g. Vilizzi et al. 2015) and topmouth gudgeon Pseudorasbora parva (e.g. Britton et al. 2010a), substantive evidence is often limited (e.g. Gozlan 2008; Gozlan et al. 2010).

A major challenge in invasion fish biology remains the assessment of impacts of introduced populations on the recipient communities and food webs (Copp et al. 2009; Tran et al. 2015). Trophic relationships that establish themselves between the introduced and native fishes can be an effective means for evaluating the potential consequences of a biological invasion for native species (Gozlan et al. 2010; Tran et al. 2015; Copp et al. 2017). The importance of these relationships is that, where they indicate dietary overlap between the species, they suggest competitive interactions could be occurring, especially in fishes of the same feeding guild and/or when food resources are limited (Griffen et al. 2008). Indeed, invasion theory predicts that following an introduction, the impact on the trophic niches of native species will vary temporally and spatially as a function of the intensity of the inter-specific feeding interactions and the availability of food resources (Tran et al. 2015). For example, where food resources are not limiting, then the introduced species can integrate into the food web with few competitive interactions with native species, enhancing their probability of establishment (Shea and Chesson 2002; Tran et al. 2015). However, where resources are more limiting, the diet of species can become specialised, as this restricts the extent of the inter-specific trophic interactions and results in the trophic niches of the species becoming constricted (Van Valen 1965; Thomson 2004; Olsson et al. 2009). Experimental field studies in support of the latter prediction are increasing (e.g. Fobert et al. 2011; Jackson and Britton 2014; Tran et al. 2015; Copp et al. 2017), and these approaches have tended to rely on stable isotope analysis (SIA) to evaluate the trophic consequences of invasion.

Amongst introduced fishes, some of the most concerning species are those introduced accidentally or illegally, as their release into the wild will have been uncontrolled, lacking risk assessment and approval by regulatory authorities (Hickley and Chare 2004; Copp et al. 2009, 2016). These fishes are often small-bodied with $r$-selected traits, which can benefit their accidental transfers via aquaculture and fisheries without detection (Davies et al. 2013), especially in cases of strong physical resemblance to a native species. An example of such a species is sunbleak Leucaspius delineatus, which is used as a model organism in the present study due to its small body size, its ability to invade both lentic (Pinder and Gozlan 2003) and lotic systems (Farr-Cox et al. 1996; Copp et al. 2006; Pollux et al. 2006) and its ability to integrate rapidly into native fish assemblages (Beyer et al. 2010). While $L$. delineatus is considered rare and vulnerable across its native range under appendix III of the Bern convention (WCMC 1996), it was introduced to Great Britain in 1986 (Gozlan et al. 2003a, b), either for ornamental purposes or, more likely, as a contaminant of an ornamental fish consignment (Farr-Cox et al. 1996). Initially, L. delineatus was primarily limited in distribution to southwest England (Farr-Cox et al. 1996; Pinder and Gozlan 2003), but has recently spread into southeast England, probably as a contaminant of anglers' gear (Zięba et al. 2010). Given the paucity of extant information on the potential impacts of $L$. delineatus on native species (Farr-Cox et al. 1996), studies initially focused on the species' environmental biology (e.g. Gozlan et al. 2003a, b), its potential role as a vector of non-native parasites (Beyer et al. 2005), and its interactions and integration with similar-sized native fishes (Beyer et al. 2010). This ability to integrate into native fish shoals, coupled with the species' similarity in diet with young native cyprinids (Gozlan et al. 2003b), suggests a high probability of inter-specific trophic and competitive interactions, given that foraging in small cyprinid fishes is more efficient as part of a shoal (Pitcher 1986).

The aim of the present study was, therefore, to assess the trophic consequences of a non-native $L$. delineatus on temperate fish assemblage in experimental ponds of uniform size and physical character. Stable isotope analysis (SIA) was the primary assessment method due to its provision of a temporally integrated dietary analytical tool that has high applicability to assessing impacts of non-native fishes (Cucherousset et al. 2012). Specific objectives were to: (1) quantify how the trophic position, carbon 
source and trophic niche size of native fishes were modified by introduced $L$. delineatus; and (2) identify any consequences of the trophic interactions for native fish growth rates and body condition. The hypothesis tested was that in L. delineatus presence, the trophic niche of native fishes will be significantly constricted, resulting in reduced growth rates and impaired body condition. Note that 'isotopic niche' in the present study refers to trophic niche, which was measured as the isotopic niche size. Whilst the isotopic niche is closely related to the trophic niche, which is a subcomponent of the ecological 'niche' (Copp 2008), it is also influenced by factors including growth rate and metabolism (Busst and Britton 2018).

\section{Materials and methods}

The experiment was completed in six outdoor experimental ponds located in southern England and constructed for research on non-native species, specifically Lepomis gibbosus (Zięba et al. 2010, 2015; Fobert et al. 2011; Copp et al. 2017). Each pond enclosed an area of $5 \times 5 \mathrm{~m}$ and consisted of a shallow 1-m wide area $(0.2-0.5 \mathrm{~m})$ on one side (see Fig. 1 in Copp et al. 2017), with the depth in the remaining area around $1.2 \mathrm{~m}$. Following the experiments in early autumn 2014 described in Copp et al. (2017), the ponds were drained, excess silt removed and left over the winter of 2014-2015 to refill with rain water and be re-populated naturally by aquatic invertebrates. Once filled, the pond water was circulated through a fiberglass cistern $\left(0.2 \mathrm{~m}^{3}\right)$ containing Canterbury spar stone chips (to facilitate microbial filtration) via a fountain pump (P2500, Bladgon, UK; maximum flow-through discharge: $2400 \mathrm{~L} \mathrm{~h}^{-1}$ ), discharging back into the pond through an overflow pipe. Any loss of water was substituted with the gravelfiltered water from a nearby pond. Each pond was lined with a plastic liner and enclosed with wooden planks raised around $30 \mathrm{~cm}$ above the ground and fitted with anti-bird netting. Temperature loggers (TinyTag Aquatic 2, Gemini Data Loggers Ltd, UK) were placed into each pond to monitor temperature changes during the experiment.

The experimental design, which effectively replicates that used by a previous study in the same ponds on the trophic consequences of L. gibbosus on native pond fishes (Copp et al. 2017), consisted of a control and a treatment with three replicates of each, with the ponds selected randomly as controls and treatments. Both the control and treatment ponds were stocked to contain an assemblage of small-sized native fishes that are characteristic of pond fish assemblages, which are rarely of equal density (Table 1): rudd Scardinius erythrophthalmus $(n=5)$, gudgeon Gobio gobio $(n=9)$ and tench Tinca tinca $(n=10)$. The control ponds contained no L. delineatus (NLd), whereas treatment ponds $(\mathrm{Ld})$ were stocked with $L$. delineatus at densities $(n=24$; Table 1$)$ that correspond with future invasion predictions under climate-change scenarios (Fobert et al. 2013).

To avoid handling stress and the resulting increased risk of mortality often observed with small fishes (Persson and Greenberg 1990), total fish mass $(M)$ at the start of the experiment was estimated from total $M$ determined using the volumetric method to: (1) ensure that similar-sized fish of each species were stocked across ponds; and (2) measure any change in total $M$ over the course of the experiment, with any progeny produced during the study period ignored to avoid bias due to reproduction. All fishes used in the experiment were available from adjacent, large angling ponds on the site except for $T$. tinca, which were obtained from an aquaculture facility. The release of native fishes into the ponds was performed on 23 March 2015, allowing the native fish and pond communities to establish, followed by $L$. delineatus release into the ponds on 19 May 2015. The experiment ended on 19 August 2015, providing sufficient time (93 days for L. delineatus and 150 days for other fish species) for fish fin tissue to achieve isotopic equilibrium with their new diet at water temperatures between 19.7 and $20.5^{\circ} \mathrm{C}$ (Thomas and Crowther 2015; Copp et al. 2017).

At the conclusion of the experiment, ponds were drained and fish recovered, counted, measured for total length $\left(L_{\mathrm{T}}\right.$, to $\left.1 \mathrm{~mm}\right)$ and weighed for mass $(M$, to $0.1 \mathrm{~g}$ ), with a sample of tissue (fin clip) for stable isotope analysis taken from a sub-sample of specimens of each species, which were under mild sedation (5 $\mathrm{mL} \mathrm{L}^{-1}$ of 2-phenoxyethanol) using a UK Home Office licensed procedure. The $L_{\mathrm{T}}$ and $M$ of each fish were used to: 1) estimate body 'condition', using the Fulton condition index $\left(K=100 \times M / L_{\mathrm{T}}^{3}\right)$, where $M$ and $L_{\mathrm{T}}$ are given in $\mathrm{g}$ and $\mathrm{cm}$, respectively,; and 2) test the effect of $L$. delineatus on body size and condition of native fishes, excluding progeny. After 
Table 1 Numbers of native ( $\mathrm{Gg}=$ Gobio gobio,

$\mathrm{Se}=$ Scardinius

erythrophthalmus,

$\mathrm{Tt}=$ Tinca tinca) and nonnative fish

(Ld = Leucaspius

delineatus) stocked into the experimental ponds

$(\mathrm{NLd}=$ no L. delineatus,

$\mathrm{Ld}=L$. delineatus present)

in March and May ( $L$.

delineatus) 2015 and re-

captured by electrofishing

in August 2015

\begin{tabular}{|c|c|c|c|c|c|c|c|}
\hline Pond & NLd1 & Ld1 & $\mathrm{Ld} 2$ & NLd2 & NLd3 & Ld3 & Total \\
\hline \multicolumn{8}{|c|}{ Total no. of fish stocked in March and May 2015} \\
\hline $\mathrm{Gg}$ & 9 & 9 & 9 & 9 & 9 & 9 & 54 \\
\hline $\mathrm{Ld}$ & 0 & 24 & 24 & 0 & 0 & 24 & 72 \\
\hline $\mathrm{Se}$ & 10 & 10 & 10 & 10 & 10 & 10 & 60 \\
\hline $\mathrm{Tt}$ & 5 & 5 & 5 & 5 & 5 & 5 & 30 \\
\hline \multicolumn{8}{|c|}{ No. of stocked fish recovered in August 2015} \\
\hline $\mathrm{Gg}$ & 4 & 6 & 7 & 5 & 3 & 5 & 30 \\
\hline $\mathrm{Ld}$ & 0 & 3 & 11 & 0 & 0 & 11 & 25 \\
\hline $\mathrm{Se}$ & 4 & 7 & 5 & 3 & 4 & 7 & 30 \\
\hline $\mathrm{Tt}$ & 5 & 5 & 5 & 5 & 5 & 5 & 30 \\
\hline \multicolumn{8}{|c|}{ No. of fish gained in August 2015 (reproduction) } \\
\hline $\mathrm{Gg}$ & 65 & 40 & 61 & 12 & 0 & 35 & 213 \\
\hline $\mathrm{Ld}$ & 0 & 287 & 0 & 0 & 0 & 0 & 287 \\
\hline $\mathrm{Se}$ & 0 & 0 & 0 & 0 & 0 & 0 & 0 \\
\hline $\mathrm{Tt}$ & 3 & 0 & 0 & 0 & 25 & 11 & 39 \\
\hline \multicolumn{8}{|c|}{ Total no. of fish recovered at the end of the experiment } \\
\hline $\mathrm{Gg}$ & 69 & 46 & 68 & 17 & 3 & 40 & 243 \\
\hline Ld & 0 & 290 & 11 & 0 & 0 & 11 & 312 \\
\hline $\mathrm{Se}$ & 4 & 7 & 5 & 3 & 4 & 7 & 30 \\
\hline $\mathrm{Tt}$ & 8 & 5 & 5 & 5 & 30 & 16 & 69 \\
\hline Total no. of native fish recovered & 81 & 58 & 78 & 25 & 37 & 63 & 342 \\
\hline NN-to-native-ratio excluding progeny & - & 0.2 & 0.6 & - & - & 0.6 & - \\
\hline NN-to-native ratio including progeny & - & 5 & 0.1 & - & - & 0.2 & - \\
\hline
\end{tabular}

processing, L. delineatus specimens were euthanized and native fish species were released back to their angling ponds of origin, following recovery from anaesthesia. Water conductivity $\left(\mu \mathrm{S} \mathrm{cm}{ }^{-1}\right)$, dissolved oxygen $\left(\mathrm{mg} \mathrm{L}^{-1}\right)$, total nitrogen $\left(\mathrm{mg} \mathrm{L}^{-1}\right)$, total phosphorous $\left(\mathrm{mg} \mathrm{L}^{-1}\right), \mathrm{pH}$ and water temperature $\left({ }^{\circ} \mathrm{C}\right)$ were assessed one day prior to fish stocking at the start of the experiment and a day before the termination of the experiment. Semi-quantitative samples of macro-invertebrates were obtained with a Freshwater Biological Association (FBA) pond net (mesh size = $900 \mu \mathrm{m})$ during a 5-min sweep, counted in the laboratory and their relative abundance was estimated.

Stable isotope analysis was performed on fish fin tissues and macro-invertebrate samples. Specifically, macro-invertebrate species used for the analysis were Gerris lacustris, Baetis spp. and Chironomidae, with each sample representing 3-9 individuals, depending on their size to ensure enough material for stable isotope analysis. Triplicate samples of each macroinvertebrate species were analysed for each pond, with the exception of bloodworms in ponds 1 and 3, and mayfly nymphs in Pond 5 for which only two replicate samples were possible due to limited numbers of those macro-invertebrates in those ponds. Fish tissue and macro-invertebrate samples were then dried at $60{ }^{\circ} \mathrm{C}$ for $24 \mathrm{~h}$ and analysed at the Cornell University Stable Isotope Laboratory (2015), New York, USA for their stable isotopes of $\delta^{13} \mathrm{C}$ and $\delta^{15} \mathrm{~N}$, expressed as isotope ratios per mille (\%o). The C:N ratios indicated very low lipid content and thus lipid extraction or normalization would have little effect on $\delta^{13} \mathrm{C}$ (Post et al. 2007), so no lipid correction was applied to the data. For detailed description of analytical procedures, see Copp et al. (2017).

Data analysis

Linear models were used to test for the difference in the initial $M$ (estimated from volumetric mass) across treatments (NLd vs. Ld) for each species (as interaction between treatment and species). In addition, 
differences in carbon and nitrogen isotopic values between macro-invertebrate baseline were tested across ponds by linear models. The relationship between $L$. delineatus $L_{\mathrm{T}}$ and $\delta^{13} \mathrm{C}$ and $\delta^{15} \mathrm{~N}$ values at recovery was also assessed with linear models independently for each pond.

Linear, mixed-effects models (LMEMs) were used to test the impact of treatment on final $L_{\mathrm{T}}, M$ and Fulton index of each species at the end of the experiment. The differences in $L_{\mathrm{T}}$ between species at recovery were also assessed with the LMEM. In addition, LMEMs were used to investigate the impact of treatment on trophic positions and corrected carbon values, with $L_{\mathrm{T}}$ as a covariate as informed by the previous model. All LMEMs were fitted by maximum likelihood in the package lme4 (Bates et al. 2015), with interaction of treatment and species as a fixed effect. Each pond was assessed as a random effect on the intercept to account for spatial dependency of individual data points.

In each case, model assumptions were validated using standard graphical validation for linear models and LMEMs in R (Zuur et al. 2009). Fitted linear models and LMEMs were evaluated by $F$-test and Wald test, respectively, with the ANOVA function in the car package in R (Fox and Weisberg 2011). Following a significant effect in each model, pair-wise comparisons of covariate-adjusted means (Students' $t$ tests and Wilcoxon $z$ tests) were conducted with single-step adjustment for $P$ values in the package multcomp in R (Hothorn et al. 2008). All the analyses were performed in $\mathrm{R}$ version 3.4.2. (R Development Core Team 2010). Complete dataset and $\mathrm{R}$ code used for the analysis and creation of figures can be found at doi: https://doi.org/10.14466/CefasDataHub.48.

Primary analysis of stable isotopes consisted of exploring biplots of $\delta^{13} \mathrm{C}$ versus $\delta^{15} \mathrm{~N}$ of fish individual data and mean macro-invertebrates values for each pond (Fig. 2). While nitrogen values of macro-invertebrates did not vary significantly among ponds (LM; $\left.F_{1,37}=0.01, P>0.05\right)$, differences in carbon values were significant $\left(\mathrm{LM} ; F_{1,37}=9.70, P<0.01\right)$. Consequently, fish isotopic values were corrected prior to further comparisons between treatments. Specifically, $\delta^{15} \mathrm{~N}$ data were transformed to trophic position (TP) using the equation $\mathrm{TP}_{\mathrm{i}}=\left[\left(\delta^{15} \mathrm{~N}_{\mathrm{i}}-\delta^{15} \mathrm{~N}_{\text {base }}\right) /\right.$ 3.4] +2 , where $\mathrm{TP}_{\mathrm{i}}$ is the trophic position of the individual fish, $\delta^{15} \mathrm{~N}_{\mathrm{i}}$ is the isotopic ratio of that fish, $\delta^{15} \mathrm{~N}_{\text {base }}$ is the isotopic ratio of the primary consumers (mean $\delta^{15} \mathrm{~N}$ of all macro-invertebrates), 3.4 is the fractionation between trophic levels and 2.0 is the trophic position of the baseline organism (Post 2002). Correction of $\delta^{13} \mathrm{C}$ was as follows: $\delta^{13} \mathrm{C}_{\text {corr }}=\delta^{13}$ $\mathrm{C}_{\mathrm{i}}-\delta^{13} \mathrm{C}_{\text {meaninv }} / \mathrm{CR}_{\mathrm{inv}}$, where $\delta^{13} \mathrm{C}_{\text {corr }}$ is the corrected carbon isotope ratio of the individual fish, $\delta^{13} \mathrm{C}_{\mathrm{i}}$ is the uncorrected isotope ratio of that fish, $\delta^{13} \mathrm{C}_{\text {meaninv }}$ is the mean invertebrate isotope ratio and $\mathrm{CR}_{\mathrm{inv}}$ is the invertebrate carbon range across all macro-invertebrate species $\left(\delta^{13} C_{\max }-\delta^{13} C_{\min }\right.$; Olsson et al. 2009). Furthermore, fractionation factors were assumed to be equal for all fish species due to lack of data on speciesspecific values.

To avoid a significant impact of fish $L_{\mathrm{T}}$ on trophic position due to significant variations in $L_{\mathrm{T}} \mathrm{s}$ between species detected at the end of the experiment (LMEM; $\chi_{(3)}^{2}=41.44, P<0.01$ ), fishes of different $L_{T}$ s were excluded from the standard ellipse area calculations. Specifically, fish with $L_{\mathrm{T}}>7 \mathrm{~cm}$ were omitted from further analysis to comply with the sizes of $L$. delineatus present in the experiment due to potential ontogenetic diet shifts, which could have compromised the analysis (Hyslop 1980; Bašić and Britton 2015). In the case of progeny of three species, those of G. gobio and T. tinca were included in the analysis because they were of similar $L_{\mathrm{T}}$ as adult $L$. delineatus, whereas $L$. delineatus progeny were excluded from further analysis due to significant differences in $\delta^{13} \mathrm{C}$ and $\delta^{15} \mathrm{~N}$ of those obtained for adult $L$. delineatus.

Corrected stable isotope data were then used to calculate the standard ellipse area (SEA) for remaining species per treatment by using the SIAR package in $\mathrm{R}$ (Jackson et al. 2011). SEA represents distribution of individuals in the isotopic space as a bivariate measure, with the ellipses encompassing $40 \%$ of data, representing the core dietary isotopic niche, hereafter referred to as 'isotopic niche' (Jackson et al. 2011, 2012, 2016). Owing to limited numbers of fish per species after $L_{\mathrm{T}}$ correction, data from different ponds were pooled by treatment, and a Bayesian estimate of SEA (SEAb) was calculated using a Markov chain Monte Carlo simulation with 20,000 iterations. This generated estimates of SEAb modes and $95 \%$ credible intervals, which were used in the subsequent comparisons of SEAb size and calculation of SEAb overlap (shared isotopic resources, including 40 and $95 \%$ of the data) between species and treatments. 


\section{Results}

Pond water chemistry variables showed little change during the course of the experiment, with minor differences found in nitrogen levels (Table 2). Macroinvertebrate species found across all experimental ponds included: Asellus aquaticus, Gerris lacustris, Lymnaea peregra, Baetis spp. Chironomidae, Corixidae juveniles, Oligochaeta, Pisidium sp., Simulidae, and Tipulidae. Their relative abundance increased throughout the experiment, by $4 \pm 2.2$ (SE) ind. per sweep in the control ponds (from $5.7 \pm 0.7$ to $9.7 \pm 2.9)$ and by $11 \pm 6.8$ ind. per sweep in the treatment ponds (from $4.3 \pm 1.7$ to $15.0 \pm 8.5$ ).

At the start of the experiment, there were no significant differences (Students' $t$ test) in the mean $M$ of $G$. gobio $(t=-0.63, P>0.05), T$. tinca $(t=-0.93, \quad P>0.05)$, or $S$. erythrophthalmus $(t=0.43, P>0.05)$, within species between treatment and control ponds (Table 3). However, there were significant differences in initial $M$ (linear model; $\left.F_{5,12}=150.1, P<0.01\right)$ among species within treatments (Table 3). At the end of the experiment, the total number of fishes recovered (excluding progeny) was generally reduced due most likely to fish mortality (and possibly sampling error), with the exception of $T$. tinca, which remained unchanged (Table 1). Regarding reproduction, progeny were observed for three species: G. gobio in all ponds except Pond NLd3; $T$. tinca in ponds NLd1, NLd3, Ld3; and L. delineatus in Pond Ld1 only. Mean $M(\mathrm{~g}), L t(\mathrm{~cm})$ and Fulton index (all $\pm \mathrm{SE}$ ), respectively, of the recovered progeny (all ponds combined) were: $G$. gobio $(0.7 \pm 0.0$,
$3.8 \pm 0.1$, and $0.8 \pm 0.0), \quad T$. tinca $(0.4 \pm 0.1$, $2.9 \pm 0.1$, and $1.1 \pm 0.1)$ and $L$. delineatus $(0.2 \pm 0.0,2.6 \pm 0.1$, and $0.6 \pm 0.0)$. All species except $L$. delineatus underwent an increase in $M$ over the course of the experiment (Table 3).

For recovered fishes excluding progeny, the LMEMs revealed a significant effect of the interaction of treatment and species on their $L_{\mathrm{T}}\left(\chi_{(5)}^{2}=140.32\right.$; $P<0.01), M\left(\chi_{(5)}^{2}=156.56 ; P<0.01\right)$ and condition $\left(\chi_{(5)}^{2}=148.23 ; \quad P<0.01\right)$. While native species decreased in $L_{\mathrm{T}}, M$ and condition index in the presence of L. delineatus, pair-wise comparisons (Wilcoxon $z$ tests) did not reveal any significant differences between control and treatment individuals of G. gobio $\left(L_{\mathrm{T}}: \quad z=1.30 ; \quad P>0.05 ; \quad M: \quad z=0.91 ; P>0.05\right.$; Fulton: $z=1.19 ; P>0.05)$ and $T$. tinca $\left(L_{\mathrm{T}}\right.$ : $z=1.47 ; P>0.05 ; M: z=2.10 ; P>0.05$; Fulton: $z=1.30 ; \quad P>0.05$ ) (Table 3; Fig. 1). The only significant differences observed were between $L_{\mathrm{T}}$ of control and treatment $S$. erythropthalmus $\left(L_{\mathrm{T}}\right.$ : $z=3.54 ; P<0.01)$, but this was not reflected in their $M(z=2.33 ; P>0.05)$ or condition index $(z=1.19$; $P>0.05)$ (Table 3; Fig. 1).

Stable isotope analysis

The differences in $\mathrm{N}$ stable isotope values between the fishes and their putative prey resources (as mean macro-invertebrates SI values) were 2-5\%o, except for the differences between $L$. delineatus and prey items, which were 3-7\%o (Fig. 2). Furthermore, L. delineatus had higher trophic position than other fish species, with differences in their SI data of 1.5-3.0\% (Fig. 2).

Table 2 Mean water chemistry variables (all pond data combined) measured at the start (March 2015) and the end (August 2015) of the pond experiment $(\mathrm{NLd}=$ no $L$. delineatus, $\mathrm{Ld}=L$. delineatus present $)$

\begin{tabular}{|c|c|c|c|c|}
\hline & \multicolumn{2}{|l|}{ Start } & \multicolumn{2}{|l|}{ End } \\
\hline & NLd & Ld & NLd & Ld \\
\hline Dissolved oxygen $\left(\mathrm{mg} \mathrm{L}^{-1}\right)$ & $6.9 \pm 0.10$ & $7.0 \pm 0.20$ & $8.1 \pm 0.10$ & $7.6 \pm 0.20$ \\
\hline $\mathrm{pH}$ & $7.7 \pm 0.20$ & $7.7 \pm 0.10$ & $7.8 \pm 0.20$ & $7.8 \pm 0.20$ \\
\hline Conductivity $\left(\mu \mathrm{S} \mathrm{cm}{ }^{-1}\right)$ & $365.0 \pm 17.30$ & $378.7 \pm 31.00$ & $401.7 \pm 48.30$ & $375.0 \pm 32.10$ \\
\hline Temperature $\left({ }^{\circ} \mathrm{C}\right)$ & $20.4 \pm 0.10$ & $20.5 \pm 0.10$ & $19.7 \pm-0.20$ & $19.9 \pm 0.20$ \\
\hline Nitrogen $\left(\mathrm{mg} \mathrm{L}^{-1}\right)$ & $14.6 \pm 7.40$ & $5.6 \pm 0.30$ & $20.9 \pm 9.40$ & $12.3 \pm 2.20$ \\
\hline Phosphorus (mg L ${ }^{-1}$ ) & $0.1 \pm 0.10$ & $0.1 \pm 0.00$ & $0.1 \pm 0.00$ & $0.1 \pm 0.03$ \\
\hline
\end{tabular}

The error around the mean is the standard error 
Table 3 Estimated mean mass ( $M$, in $\mathrm{g}$; from volumetric mass) of non-native ( $\mathrm{Ld}=$ Leucaspius delineatus $)$ and native fishes $(\mathrm{Gg}=$ Gobio gobio, $\mathrm{Se}=$ Scardinius erythrophthalmus, $\mathrm{Tt}=$ Tinca tinca $)(\dagger=\mathrm{Ld}$ present $)$ at stocking and measured mean $M(\mathrm{~g}), L_{\mathrm{T}}(\mathrm{cm})$ and Fulton index at recovery $( \pm \mathrm{SE})$ without progeny, including mean difference in $M$ during the experiment and means of all the variables across ponds (n/ $\mathrm{a}=$ not applicable)

\begin{tabular}{|c|c|c|c|c|c|c|c|}
\hline Pond & 1 & $2^{\dagger}$ & $3^{\dagger}$ & 4 & 5 & $6 \dagger$ & Means \\
\hline \multicolumn{8}{|c|}{ Mean estimated $M$ of fish prior to stocking } \\
\hline $\mathrm{Gg}$ & 10.8 & 10.8 & 10.4 & 9.8 & 9.5 & 10.8 & 10.4 \\
\hline $\mathrm{Ld}$ & $\mathrm{n} / \mathrm{a}$ & 1.5 & 1.4 & $\mathrm{n} / \mathrm{a}$ & $\mathrm{n} / \mathrm{a}$ & 1.4 & 1.4 \\
\hline $\mathrm{Se}$ & 7.4 & 6.6 & 6.6 & 7.1 & 6.4 & 6.4 & 6.8 \\
\hline $\mathrm{Tt}$ & 21.7 & 26.2 & 24.4 & 26.0 & 26.6 & 26.5 & 25.2 \\
\hline \multicolumn{8}{|c|}{ Mean measured $M$ of fish at recovery $( \pm \mathrm{SE})$} \\
\hline $\mathrm{Gg}$ & $17.7 \pm 1.1$ & $15.9 \pm 0.6$ & $10.6 \pm 0.6$ & $22.0 \pm 1.7$ & $18.7 \pm 1.5$ & $15.7 \pm 1.7$ & 16.8 \\
\hline $\mathrm{Ld}$ & $\mathrm{n} / \mathrm{a}$ & $0.9 \pm 0.03$ & $1.4 \pm 0.1$ & $\mathrm{n} / \mathrm{a}$ & $\mathrm{n} / \mathrm{a}$ & $1.4 \pm 0.1$ & 1.2 \\
\hline $\mathrm{Se}$ & $16.4 \pm 2.3$ & $9.3 \pm 1.9$ & $9.9 \pm 1.6$ & $29.5 \pm 4.8$ & $24.7 \pm 2.2$ & $15.2 \pm 0.9$ & 17.5 \\
\hline $\mathrm{Tt}$ & $37.9 \pm 3.1$ & $39.2 \pm 8.6$ & $26.8 \pm 3.0$ & $60.0 \pm 7.5$ & $34.5 \pm 2.7$ & $33.5 \pm 2.5$ & 38.7 \\
\hline \multicolumn{8}{|c|}{ Mean measured $L_{\mathrm{T}}$ of fish at recovery $( \pm \mathrm{SE})$} \\
\hline $\mathrm{Gg}$ & $12.2 \pm 0.3$ & $12.1 \pm 0.1$ & $11.1 \pm 0.1$ & $13.0 \pm 0.3$ & $12.7 \pm 0.3$ & $12.1 \pm 0.5$ & 12.2 \\
\hline $\mathrm{Ld}$ & $\mathrm{n} / \mathrm{a}$ & $5.2 \pm 0.1$ & $5.3 \pm 0.1$ & $\mathrm{n} / \mathrm{a}$ & $\mathrm{n} / \mathrm{a}$ & $5.5 \pm 0.3$ & 5.4 \\
\hline $\mathrm{Se}$ & $10.9 \pm 0.6$ & $9.4 \pm 0.6$ & $9.7 \pm 0.6$ & $13.2 \pm 0.8$ & $12.5 \pm 0.3$ & $10.4 \pm 0.2$ & 11.0 \\
\hline $\mathrm{Tt}$ & $14.0 \pm 0.3$ & $14.4 \pm 0.7$ & $13.0 \pm 0.5$ & $16.1 \pm 0.7$ & $13.4 \pm 0.5$ & $13.2 \pm 0.4$ & 14.0 \\
\hline \multicolumn{8}{|c|}{ Mean Fulton index of fish at recovery $( \pm \mathrm{SE})$} \\
\hline $\mathrm{Gg}$ & $1.0 \pm 0.02$ & $0.9 \pm 0.02$ & $0.8 \pm 0.03$ & $1.0 \pm 0.04$ & $0.9 \pm 0.03$ & $0.9 \pm 0.03$ & 0.9 \\
\hline $\mathrm{Ld}$ & $\mathrm{n} / \mathrm{a}$ & $0.7 \pm 0.01$ & $0.9 \pm 0.04$ & $\mathrm{n} / \mathrm{a}$ & $\mathrm{n} / \mathrm{a}$ & $0.9 \pm 0.1$ & 0.8 \\
\hline $\mathrm{Se}$ & $1.3 \pm 0.1$ & $1.0 \pm 0.04$ & $1.1 \pm 0.03$ & $1.3 \pm 0.1$ & $1.3 \pm 0.1$ & $1.4 \pm 0.1$ & 1.3 \\
\hline $\mathrm{Tt}$ & $1.4 \pm 0.04$ & $1.2 \pm 0.1$ & $1.2 \pm 0.02$ & $1.4 \pm 0.03$ & $1.4 \pm 0.1$ & $1.5 \pm 0.01$ & 1.4 \\
\hline \multicolumn{8}{|c|}{ Difference in mean $M$ over the course of the experiment } \\
\hline $\mathrm{Gg}$ & 6.9 & 6.1 & 0.2 & 12.8 & 9.2 & 4.9 & 6.7 \\
\hline $\mathrm{Ld}$ & $\mathrm{n} / \mathrm{a}$ & -0.6 & 0.0 & $\mathrm{n} / \mathrm{a}$ & $\mathrm{n} / \mathrm{a}$ & 0.0 & -0.2 \\
\hline $\mathrm{Se}$ & 9.0 & 2.7 & 3.3 & 22.4 & 18.3 & 8.8 & 10.8 \\
\hline $\mathrm{Tt}$ & 16.2 & 13.0 & 2.4 & 34.0 & 7.9 & 7.0 & 13.4 \\
\hline
\end{tabular}

In general, there was no significant effect of $L$. delineatus $L_{\mathrm{T}}$ on carbon or nitrogen isotopic values, with the exception of the Pond Ld1, where individuals of short $L_{\mathrm{T}}$ had quite low nitrogen values (Fig. 3).

Comparisons of stable isotope values between treatments used the corrected data (Table 4). Linear mixed-effect models indicated a significant impact of treatment and species interaction (LMEMs; Wald $\chi^{2}$ ) on both corrected carbon $\left(\chi_{(5)}^{2}=35.10 ; P<0.01\right)$ and trophic position $\left(\chi_{(5)}^{2}=41.56 ; P<0.01\right)$, with the covariate of $L_{\mathrm{T}}$ significant only for trophic position $\left(\chi_{(1)}^{2}=39.58 ; P<0.01\right.$ ). Multiple comparisons (Wilcoxon $\mathrm{z}$ tests) of estimated marginal means (with Tukey contrasts) revealed no significant differences between control (NLd) and treatment (Ld) corrected carbon values of G. gobio $(z=0.65, P>0.05), T$. tinca $(z=0.41, P>0.05)$ or $S$. erythrophthalmus $(z=1.04, P>0.05)$ (Fig. 4). Equally, trophic position between control and treatment (Fig. 4) did not differ significantly in G. gobio $(z=0.41, P>0.05), T$. tinca $(z=1.81, P>0.05)$ or $S$. erythrophthalmus $(z=-0.88, P>0.05)$. Significant differences in corrected carbon values were evident between $G$. gobio and S. erythrophthalmus in the presence of $L$. delineatus $(z=4.66, P<0.01)$, with no differences observed in the control $(z=-2.44, P>0.05)$. Similarly, differences in corrected carbon values beween G. gobio and T. tinca were significant in the control ( $z=3.70, P<0.01$ ), whereas no significant change between them was evident in the presence of $L$. delineatus $(z=2.64, P>0.05)$. Trophic position differed significantly between G. gobio and S. erythrophthalmus $(z=-5.30, P<0.01)$ and $T$. tinca and $S$. erythrophthalmus $(z=-5.24, P<0.01)$ in the 

effects and $95 \%$ confidence intervals estimated from testing the impact of Treatment $(\mathrm{NLd}=$ no $L$. delineatus, $\mathrm{Ld}=L$. total length, mass and Fulton body index of native fishes at recovery, where: clear triangle $=T$. tinca, clear square $=G$. gobio, $\times=S$. erythrophthalmus
Fig. 1 Mean marginal mixed-effects models delineatus present) on the
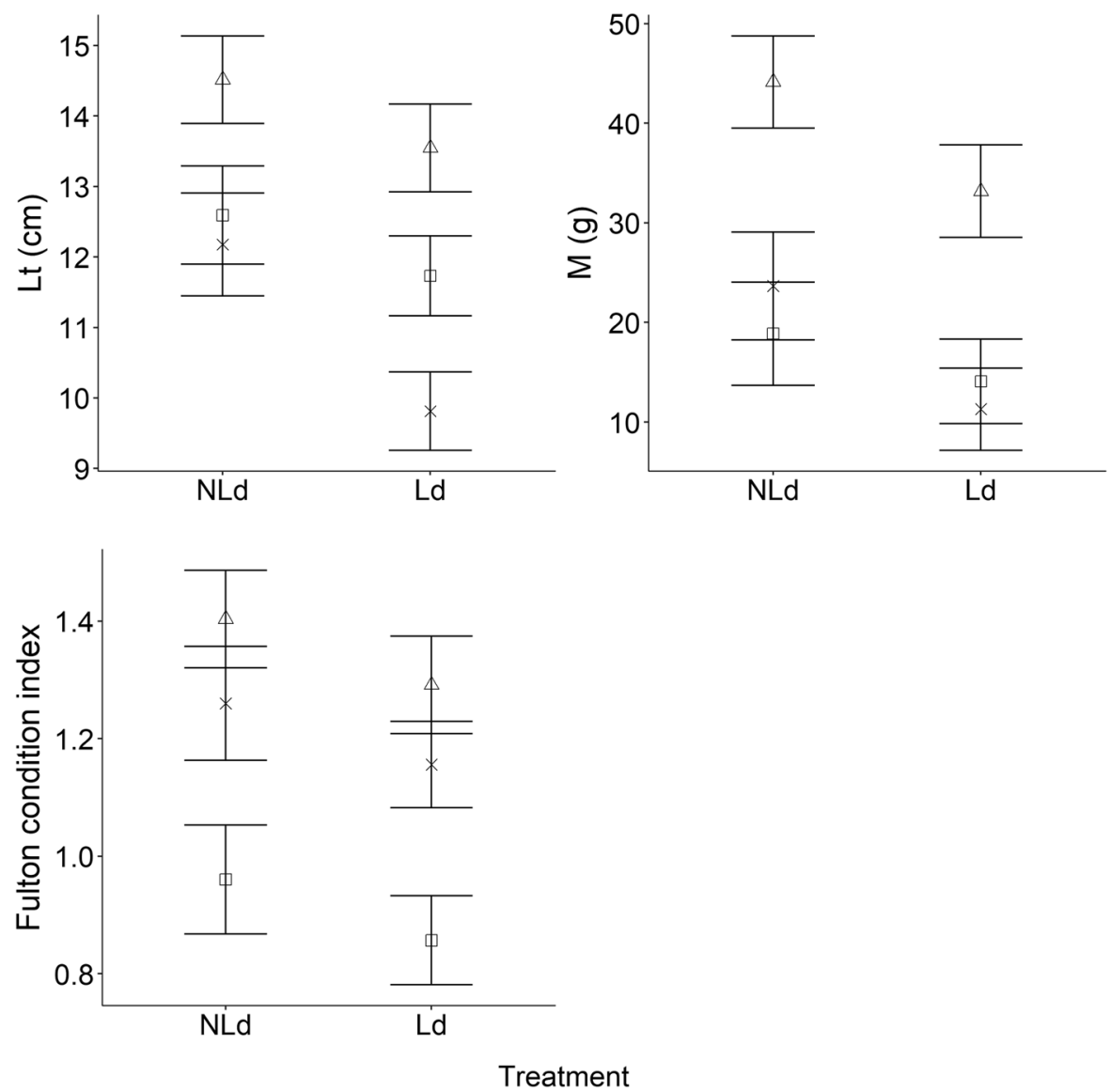

presence of L. delineatus. However, in the absence of L. delineatus, no significant differences were evident between G. gobio and $S$. erythrophthalmus $(z=-2.56, P>0.05)$ or $T$. tinca and S. erythrophthalmus $(z=-0.47, P>0.05)$.

Stable isotope analysis of fish of similar $L_{\mathrm{T}}$ demonstrated no overlap between core isotopic niches of L. delineatus and G. gobio or T. tinca (Table 5; Fig. 5). Equally, no overlaps in isotopic niches (comprising 95\% the data) were evident between $L$. delineatus and G. gobio, nor between L. delineatus and T. tinca (Table 5; Fig. 5). Size of the core Bayesian ellipse areas differed significantly between fish species ( $100 \%$ probability), with $L$. delineatus utilising the largest isotopic niche $\left(0.27 \%{ }^{2}\right.$; Table 5; Fig. 5). Also, Bayesian ellipse areas of G. gobio and T. tinca were significantly decreased in the presence of $L$. delineatus, with high probabilities (100\%) that ellipse sizes of both G. gobio and T. tinca were smaller than in the control ponds (Table 5; Fig. 5).

\section{Discussion}

In the experimental ponds with $L$. delineatus present, there were significant reductions in trophic niches of G. gobio and T. tinca, suggesting that the response in native fishes was niche constriction via trophic specialisation when co-habiting with $L$. delineatus. This result is consistent with similar studies on the trophic impacts on native fishes of non-native $L$. gibbosus (Copp et al. 2017) and invasive P. parva (Jackson and Britton 2014; Tran et al. 2015). It also aligns with the niche variation hypothesis, which predicts less-generalised diet of subordinate competitors under increased inter-specific competition with other species (Van Valen 1965; Thomson 2004; Olsson et al. 2009; Jackson et al. 2012). However, negative consequences for the growth or body condition for two of the three native species in this experiment. the presence of introduced $L$. delineatus had no 
Fig. 2 Stable isotope biplots per pond with control $\mathrm{NLd}=$ no L. delineatus and treatment $\mathrm{Ld}=L$.

delineatus present, where clear triangle $=T$. tinca, clear square $=$ G. gobio, $\times=S$. erythrophthalmus, filled circle $=L$. delineatus and clear circle $=$ mean macro-invertebrate stable isotope data $( \pm \mathrm{SE})$

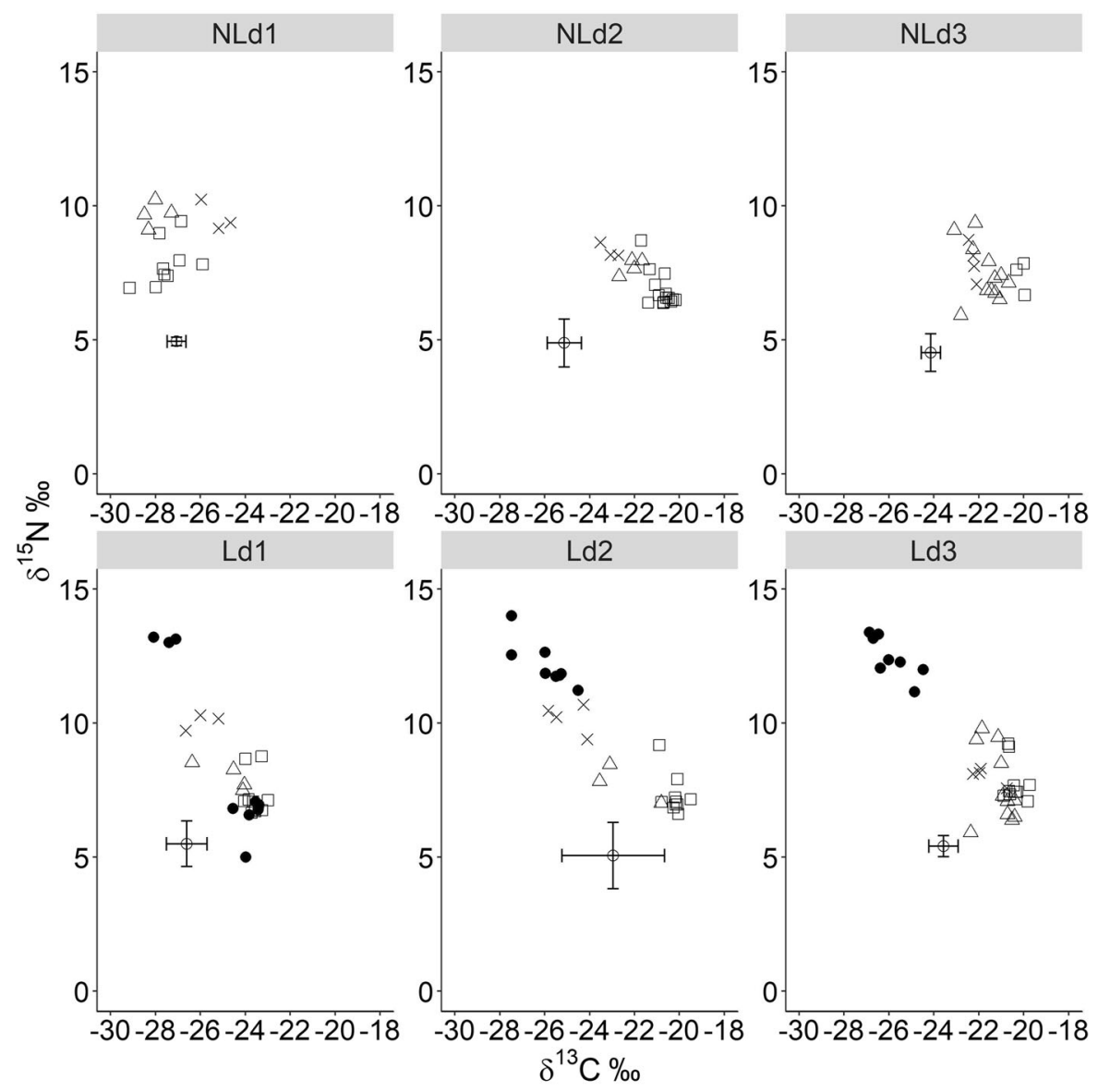

The isotopic niches of $L$. delineatus and native fishes did not overlap when $40 \%$ or $95 \%$ of the data were included. Furthermore, no effects of $L$. delineatus on size $\left(L_{\mathrm{T}}, M\right)$ or body plumpness (Fulton condition index) of two of the three native fish species were detected. This could imply that interactions between non-native and native species were not strong enough to cause perceivable detrimental effects on fish growth and well-being, such as was reported in similar experiments in these same ponds between native fishes and introduced $L$. gibbosus (Copp et al. 2017). This could be a result of limited numbers of fish utilised in this experiment, which could have prevented densitydependent effects, specifically growth impairment to occur (Britton et al. 2017). Alternatively, this could suggest that food resources were not limiting, as observed in Bašić and Britton (2016), enabling native fishes to reduce their isotopic niche in the presence of elevated numbers of non-native species, whilst maintaining their energy requirements.
Climate-change predictions could favour fast colonisation of non-native species introduced outside their native range (Rahel and Olden 2008; Fobert et al. 2013). Mitigation efforts will include fast detection of non-native species in the environment, prediction of their potential for successful establishment and spread, as well as the evaluation of the risk they pose to the receiving environment and adjacent biota (Copp et al. 2016). Consequently, with the paucity of knowledge on some non-native freshwater fishes and their ecological impacts in the UK, there is a requirement for further studies to prioritise high-risk species and develop adequate mitigation measures. Of the extant non-native fishes in the UK, L. delineatus had been previously been found to create closer social interactions with young-of-the-year cyprinid fish species of similar size than did native species amongst themselves (Beyer et al. (2010), but information on the ecological consequences of those relationships are limited to the species' potential host of an existing 
Fig. 3 Scatter plots of $\delta^{13} \mathrm{C}$ (left side) and $\delta^{15} \mathrm{~N}$ (right side) as a function of total length of $L$. delineatus in each experimental pond. Effect of L. delineatus total length on stable isotope values was tested with ANOVA for each pond; $\mathrm{Ld} 1$ $\left(\delta^{13} \mathrm{C}: F_{1,8}=14.43\right.$, $P<0.01 ; \delta^{15} \mathrm{~N}$ :

$\left.F_{1,8}=11.86, P<0.01\right)$, Ld2 $\left(\delta^{13} \mathrm{C}: F_{1,6}=4.20\right.$, $P>0.05 ; \delta^{15} \mathrm{~N}: F_{1,6}=3.57$, $P>0.05), \operatorname{Ld} 3\left(\delta^{13} \mathrm{C}\right.$ : $F_{1,6}=4.31, P>0.05 ; \delta^{15} \mathrm{~N}$ : $F_{1,6}=0.10, P>0.05$ )

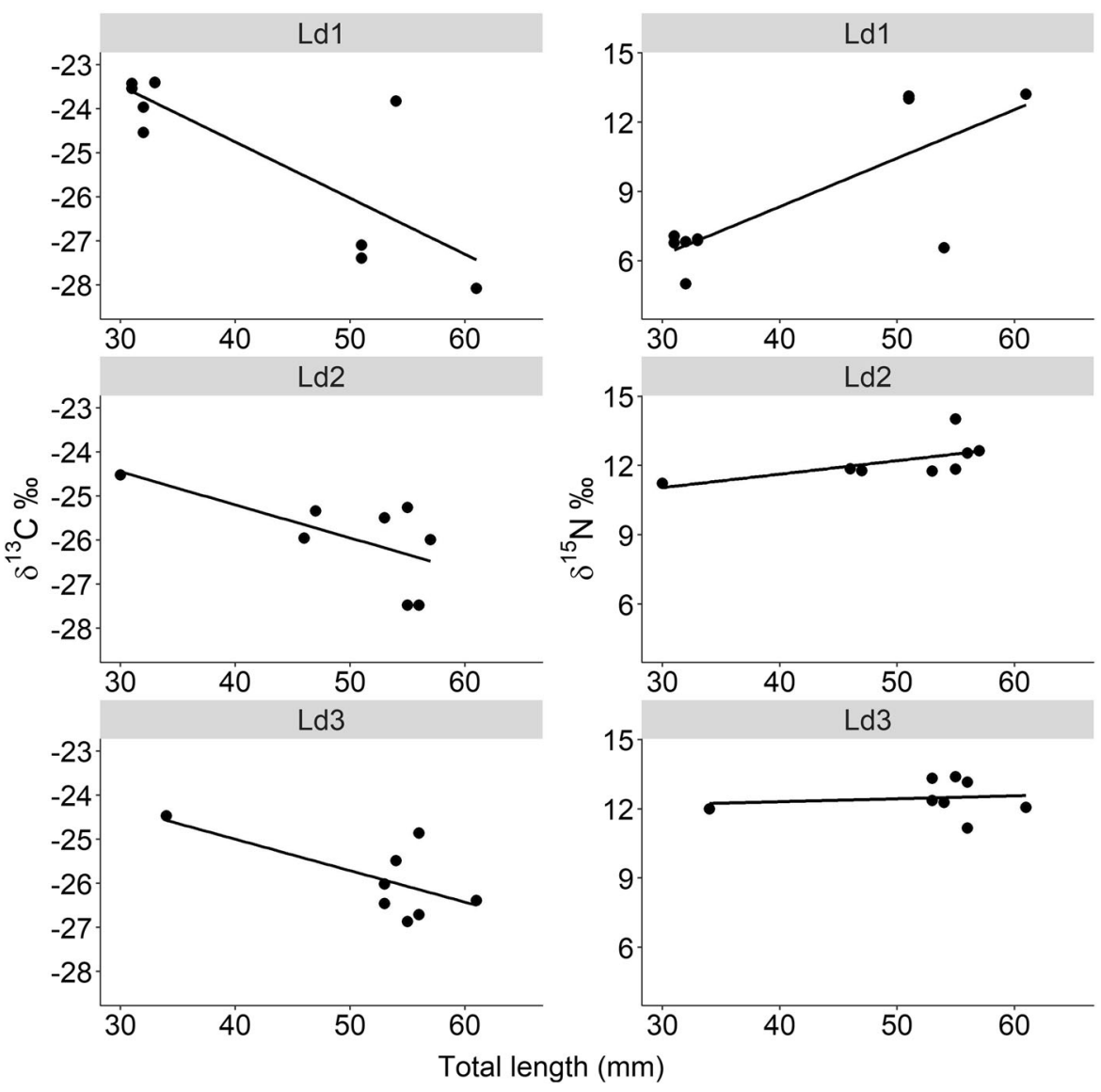

non-native fish parasite (Beyer et al. 2005) and the present results. Earlier studies on L. delineatus examined their potential for invading British rivers, including the species' reproductive strategy (Gozlan et al. 2003a), small body size (Gozlan et al. 2003b), morphology, growth and life-history traits, natural dispersal, dietary overlap, and the aforementioned parasite fauna (Beyer 2008). However, in a modelling study of climate compatibility under future climate conditions, $L$. delineatus was one of two species (the other being ide Leuciscus idus) predicted to be less compatible with warmer conditions (Britton et al. 2010b), indicating that climate change might diminish their impact on native species. However, one could argue that temperature conditions in this study could represent future climate conditions of large ponds and small lakes, as the water temperatures were $\approx 2{ }^{\circ} \mathrm{C}$ higher than the mean summer water temperatures recorded for a 0.8 ha ornamental pond $\approx 100 \mathrm{~km}$ to the north (based on data derived by Tarkan et al. 2011). This would suggest that the trophic impacts of $L$. delineatus observed in the present experimental study, under elevated temperatures than normally observed in larger ponds, may be indicative of the species' response to future climate conditions. This could be interpreted as contradicting the predictions of Britton et al. (2010b), but the short-term study results presented here must be viewed within their context: the size of the experimental ponds was $\approx 13 \%$ of the mean surface area (i.e. 0.019 ha) of garden ponds in the UK (Davies et al., 2009), the latter mean area being $\approx 7 \%$ of landscape-situated ponds (Davies et al., 2008). As such, the present results may be suggestive of future impacts, but climate change is also likely to affect the abundance and growth rates of native fish populations (Ruiz-Navarro et al. 2016) as well as the strength of some of trophic interactions (e.g. Van der Putten et al. 2010). So, the extent and magnitude of future impacts by $L$. delineatus on biotic interactions across trophic levels remain unclear.

The present study encountered a few limitations. Firstly, identical fractionation factors between fin 
Table 4 Sample sizes $(n)$, mean total lengths $\left(L_{\mathrm{T}}\right)$ and SE in $\mathrm{cm}$ of non-native ( $\mathrm{Ld}=$ Leucaspius delineatus) and native fish $(\mathrm{Gg}=$ Gobio gobio, $\mathrm{Se}=$ Scardinius erythrophthalmus, $\mathrm{Tt}$ $=$ Tinca tinca ) species (Sp.) used in the stable isotopes analysis

\begin{tabular}{|c|c|c|c|c|c|c|c|c|c|}
\hline Pond & Sp. & $n$ & Mean $L_{\mathrm{T}}$ & Mean $\delta^{13} \mathrm{C}$ & Mean Ccor & $\mathrm{CR}$ & Mean $\delta^{15} \mathrm{~N}$ & Mean TP & NR \\
\hline \multirow[t]{3}{*}{ NLd1 } & $\mathrm{Gg}$ & 9 & $48.3 \pm 15.0$ & $-27.5 \pm 0.3$ & $-0.1 \pm 0.1$ & 3.2 & $7.8 \pm 0.3$ & $2.9 \pm 0.1$ & 2.5 \\
\hline & $\mathrm{Se}$ & 3 & $112.0 \pm 10.8$ & $-25.3 \pm 0.4$ & $0.5 \pm 0.1$ & 1.3 & $9.6 \pm 0.3$ & $3.4 \pm 0.1$ & 1.1 \\
\hline & $\mathrm{Tt}$ & 4 & $112.3 \pm 23.1$ & $-28.0 \pm 0.3$ & $-0.3 \pm 0.1$ & 1.2 & $9.7 \pm 0.2$ & $3.4 \pm 0.1$ & 1.1 \\
\hline \multirow[t]{3}{*}{$\mathrm{NLd} 2$} & $\mathrm{Gg}$ & 14 & $72.1 \pm 10.4$ & $-20.8 \pm 0.1$ & $0.9 \pm 0.0$ & 1.5 & $6.9 \pm 0.2$ & $2.6 \pm 0.1$ & 2.3 \\
\hline & $\mathrm{Se}$ & 3 & $142.7 \pm 10.9$ & $-23.1 \pm 0.2$ & $0.4 \pm 0.0$ & 0.8 & $8.3 \pm 0.2$ & $3.0 \pm 0.0$ & 0.5 \\
\hline & $\mathrm{Tt}$ & 4 & $135.8 \pm 6.7$ & $-22.1 \pm 0.2$ & $0.6 \pm 0.0$ & 1.0 & $7.7 \pm 0.1$ & $2.8 \pm 0.0$ & 0.6 \\
\hline \multirow[t]{3}{*}{ NLd3 } & $\mathrm{Gg}$ & 3 & $129.0 \pm 2.5$ & $-20.1 \pm 0.1$ & $1.7 \pm 0.0$ & 0.4 & $7.4 \pm 0.4$ & $2.8 \pm 0.1$ & 1.2 \\
\hline & $\mathrm{Se}$ & 4 & $104.5 \pm 21.0$ & $-22.3 \pm 0.1$ & $0.8 \pm 0.0$ & 0.3 & $7.9 \pm 0.3$ & $3.0 \pm 0.1$ & 1.7 \\
\hline & $\mathrm{Tt}$ & 12 & $70.3 \pm 12.7$ & $-21.7 \pm 0.2$ & $1.1 \pm 0.1$ & 2.4 & $7.5 \pm 0.3$ & $2.9 \pm 0.1$ & 3.4 \\
\hline \multirow[t]{4}{*}{ Ld1 } & $\mathrm{Ld}$ & 10 & $40.9 \pm 3.7$ & $-24.9 \pm 0.6$ & $0.4 \pm 0.1$ & 4.7 & $8.5 \pm 1.0$ & $2.9 \pm 0.3$ & 8.2 \\
\hline & $\mathrm{Gg}$ & 10 & $58.0 \pm 3.3$ & $-23.6 \pm 0.1$ & $0.6 \pm 0.0$ & 1.1 & $7.3 \pm 0.2$ & $2.5 \pm 0.1$ & 2.1 \\
\hline & $\mathrm{Se}$ & 3 & $96.3 \pm 13.8$ & $-26.0 \pm 0.4$ & $0.1 \pm 0.1$ & 1.5 & $10.1 \pm 0.2$ & $3.3 \pm 0.1$ & 0.6 \\
\hline & $\mathrm{Tt}$ & 4 & $144.3 \pm 9.7$ & $-24.8 \pm 0.5$ & $0.4 \pm 0.1$ & 2.3 & $8.0 \pm 0.2$ & $2.7 \pm 0.1$ & 1.0 \\
\hline \multirow[t]{4}{*}{ Ld2 } & $\mathrm{Ld}$ & 8 & $49.9 \pm 3.2$ & $-25.9 \pm 0.4$ & $-0.3 \pm 0.0$ & 3.0 & $12.2 \pm 0.3$ & $4.1 \pm 0.1$ & 2.8 \\
\hline & $\mathrm{Gg}$ & 10 & $67.1 \pm 11.1$ & $-20.2 \pm 0.1$ & $0.2 \pm 0.0$ & 1.4 & $7.3 \pm 0.2$ & $2.7 \pm 0.1$ & 2.6 \\
\hline & $\mathrm{Se}$ & 4 & $102.3 \pm 13.5$ & $-24.9 \pm 0.4$ & $-0.2 \pm 0.0$ & 1.7 & $10.2 \pm 0.3$ & $3.5 \pm 0.1$ & 1.3 \\
\hline & $\mathrm{Tt}$ & 3 & $116.3 \pm 5.5$ & $-22.5 \pm 0.8$ & $0.0 \pm 0.1$ & 2.7 & $7.8 \pm 0.4$ & $2.8 \pm 0.1$ & 1.4 \\
\hline \multirow[t]{4}{*}{ Ld3 } & $\mathrm{Ld}$ & 8 & $52.8 \pm 2.8$ & $-25.9 \pm 0.3$ & $-0.5 \pm 0.1$ & 2.4 & $12.5 \pm 0.3$ & $4.1 \pm 0.1$ & 2.2 \\
\hline & $\mathrm{Gg}$ & 10 & $57.4 \pm 9.0$ & $-20.4 \pm 0.1$ & $0.7 \pm 0.0$ & 1.1 & $7.8 \pm 0.2$ & $2.7 \pm 0.1$ & 2.2 \\
\hline & $\mathrm{Se}$ & 4 & $95.0 \pm 20.6$ & $-21.7 \pm 0.3$ & $0.4 \pm 0.1$ & 1.5 & $8.0 \pm 0.2$ & $2.8 \pm 0.0$ & 0.7 \\
\hline & $\mathrm{Tt}$ & 11 & $61.1 \pm 14.6$ & $-21.1 \pm 0.2$ & $0.5 \pm 0.0$ & 2.0 & $7.6 \pm 0.4$ & $2.7 \pm 0.1$ & 3.9 \\
\hline
\end{tabular}

tissues and prey items were used due to limited information on species-specific values, despite the existence of variable fractionation factors for different fish species and prey items (Tronquart et al. 2012; Busst et al. 2015; Busst and Britton 2016). Secondly, observed niche constrictions of native species could be argued to be a result of density-dependent processes due to the elevated densities of stocked $L$. delineatus, i.e. irrespective of their non-native status. However, elevated densities of a non-native species during initial establishment is characteristic of many biological invasions, leading to exacerbated trophic pressures on the native species (e.g. Britton et al. 2010b; Britton and Gozlan 2013; Britton et al. 2017; Copp et al. 2017), which the present study endeavoured to evaluate. Thirdly, and ignoring the presence of progeny of three species (c.f. Results), low recovery rates for $G$. gobio and S. erythrophthalmus in several ponds could have affected the results. Finally, the present study was simplistic in design and therefore difficult to scale and their corresponding means and SE (in \%o) for $\delta^{13} \mathrm{C}, \delta^{15} \mathrm{~N}$, corrected values (Ccor and TP) and ranges of $\delta^{13} \mathrm{C}(\mathrm{CR})$ and $\delta^{15} \mathrm{~N}(\mathrm{NR})$ per experimental pond $(\mathrm{NLd}=$ no L. delineatus, $\mathrm{Ld}=$ L. delineatus present) 
Fig. 4 Mean marginal effects and $95 \%$ confidence intervals estimated from mixed-effects models testing the impact of Treatment $(\mathrm{NLd}=$ no $L$. delineatus, $\mathrm{Ld}=L$. delineatus present) on the corrected carbon and trophic position of native fishes at recovery, where: clear triangle $=T$. tinca, clear square $=G$. gobio, $\times=S$. erythrophthalmus
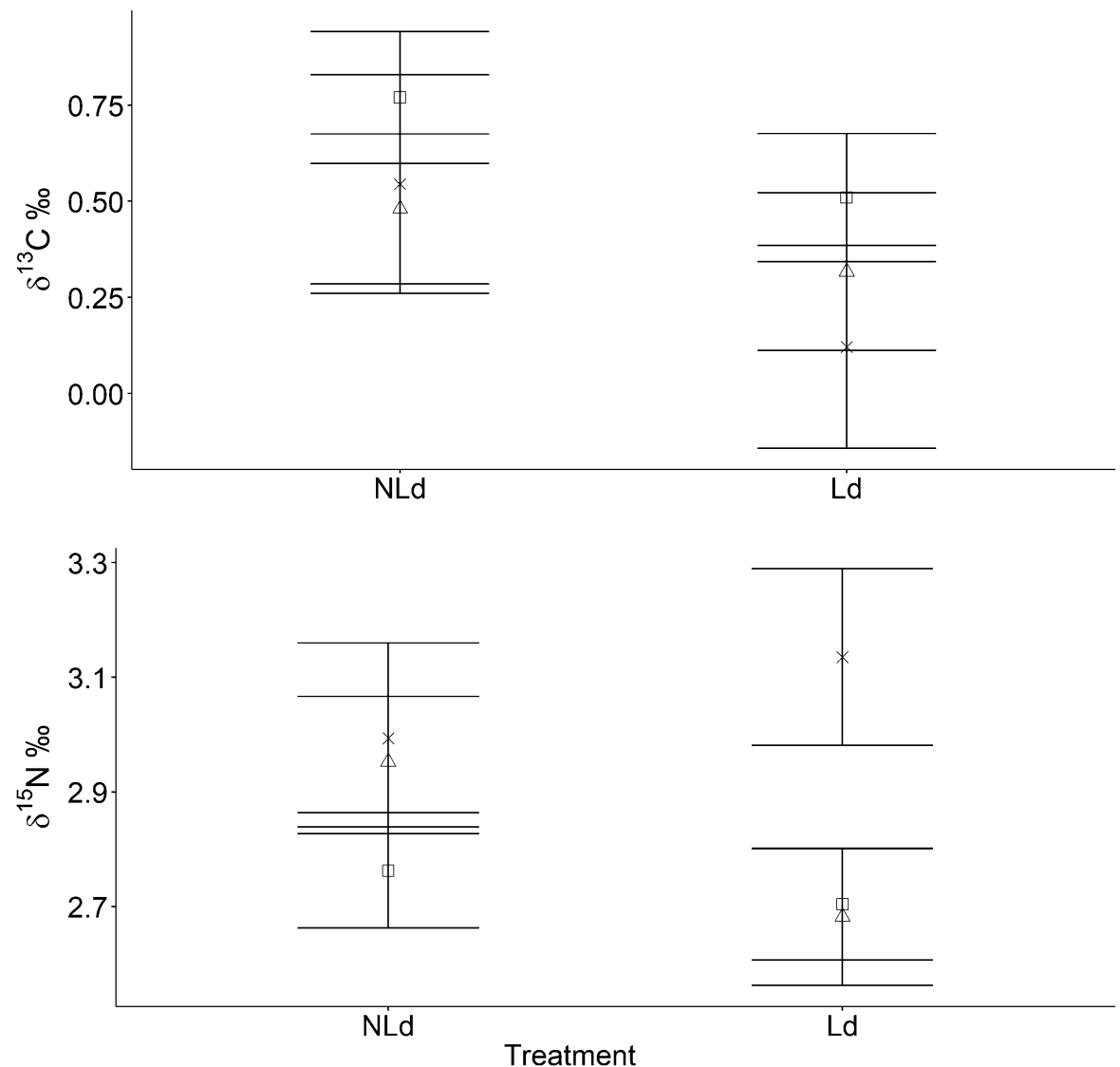

Table 5 Sample sizes $(n)$ and mean initial total length $\left(L_{T}\right)$ in $\mathrm{mm}$ of non-native ( $\mathrm{Ld}=$ Leucaspius delineatus $)$ and native fish $(\mathrm{Gg}=$ Gobio gobio, $\mathrm{Tt}=$ Tinca tinca $)$ species $(\mathrm{Sp}$.$) used for$ the analysis of the standard ellipse areas and their means $\left( \pm \mathrm{SE}\right.$ ) of corrected $\delta^{13} \mathrm{C}$ (Ccorr) and $\delta^{15} \mathrm{~N}$ (trophic position $=\mathrm{TP})$ in $\%$, as well as the species' trophic niche sizes (mode of the core Bayesian standard ellipse areas; SEAb in
$\%_{0}^{2}$, with $95 \%$ credible intervals) at the conclusion of the pond mesocosm experiment $(\mathrm{NLd}=$ no $L$. delineatus, $\mathrm{Ld}=L$. delineatus present), and the trophic niche overlaps (as \% SEAb with 95\% credible intervals) between $\mathrm{Ld}$ and $\mathrm{Gg}$ and $\mathrm{Ld}$ and $\mathrm{Tt}$, including $40 \%$ of data (core trophic niche; $\mathrm{Ov}^{40 \%}$ ) and $95 \%$ of the data $\left(\mathrm{Ov}^{95 \%}\right)$

\begin{tabular}{|c|c|c|c|c|c|c|c|c|}
\hline Treatment & Sp. & $n$ & $L_{\mathrm{T}}$ & Ccorr & $\mathrm{TP}$ & SEAb & $\mathrm{Ov}^{40 \%}$ & $\mathrm{Ov}^{95 \%}$ \\
\hline \multirow[t]{2}{*}{ NLd } & $\mathrm{Gg}$ & 18 & $4.3 \pm 0.4$ & $0.5 \pm 0.1$ & $2.6 \pm 0.0$ & $0.28(0.18-0.46)$ & & \\
\hline & $\mathrm{Tt}$ & 9 & $4.1 \pm 0.3$ & $1.0 \pm 0.2$ & $2.7 \pm 0.1$ & $0.32(0.17-0.69)$ & & \\
\hline \multirow[t]{3}{*}{$\mathrm{Ld}$} & $\mathrm{Ld}$ & 18 & $5.4 \pm 0.1$ & $-0.3 \pm 0.1$ & $4.0 \pm 0.1$ & $0.27(0.16-0.43)$ & & \\
\hline & $\mathrm{Gg}$ & 24 & $4.8 \pm 0.1$ & $0.5 \pm 0.0$ & $2.5 \pm 0.0$ & $0.09(0.06-0.13)$ & 0 & 0 \\
\hline & $\mathrm{Tt}$ & 7 & $2.7 \pm 0.2$ & $0.6 \pm 0.1$ & $2.4 \pm 0.1$ & $0.05(0.02-0.12)$ & 0 & 0 \\
\hline
\end{tabular}

them to maintain their growth rates and condition in the face of possible invasion.

Acknowledgements This study was funded mainly by a research contract (SF0269) to GHC from the UK Department of Environment, Food and Rural Affairs (Defra), with a financial contribution from Bournemouth University (research grants to JRB). EK's participation in this study was supported by a Short
Term Scientific Mission under COST Action TD1209 'ALIEN Challenge'. The study would not have been possible without access permission from the owners (B. and S. Brown) of Tanyard Fishery, where the experimental ponds were built by the owners at minimal cost to Cefas for this and previous field studies of non-native fishes. We are extremely grateful for their kind support and warm welcome when working on their premises. 
Fig. 5 Stable isotope biplots for each treatment with individual data points and solid and dashed lines enclosing $40 \%$ and $95 \%$ of the standard ellipse areas for each species, respectively, where: Upper graph-T. tinca in presence (clear black circles and black line) and absence (clear dark grey triangles and dark grey line) of L. delineatus; Middle graph-G. gobio in presence (clear black circles and black line) and absence (clear dark grey triangles and dark grey line) of $L$. delineatus; Lower graphL. delineatus (clear black circles and black line), $G$. gobio (clear grey triangles and grey line) and T. tinca (clear dark grey squares and dark grey line) in the ponds with $L$. delineatus
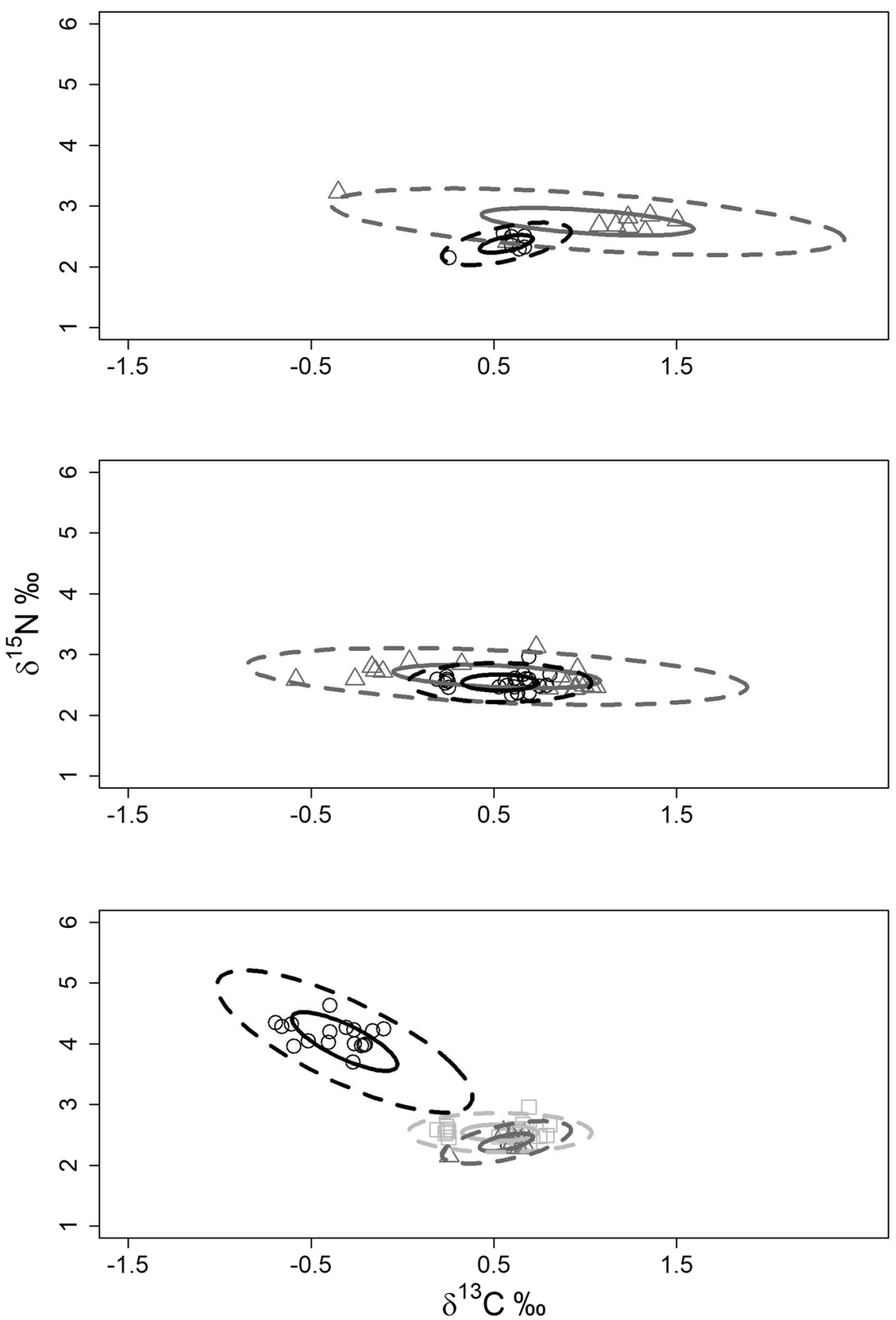

Open Access This article is distributed under the terms of the Creative Commons Attribution 4.0 International License (http:// creativecommons.org/licenses/by/4.0/), which permits unrestricted use, distribution, and reproduction in any medium, provided you give appropriate credit to the original author(s) and the source, provide a link to the Creative Commons license, and indicate if changes were made.

\section{References}

Bašić T, Britton JR (2015) Utility of fish scales from stock assessment surveys in stable isotope analysis for initial assessments of trophic relationships in riverine fish communities. J Appl Ichthyol 31:296-300

Bašić T, Britton JR (2016) Characterizing the trophic niches of stocked and resident cyprinid fishes: consistency in 
partitioning over time, space and body sizes. Ecol Evol 6:5093-5104

Bates D, Maechler M, Bolker B, Walker S (2015) Fitting linear mixed-effects models using lme4. J Stat Softw 67:1-48

Beyer K (2008) Ecological implications of introducing Leucaspius delineatus (Heckel, 1843) and Pseudorasbora parva (Temminck and Schlegel, 1842) into inland waters in England. PhD Thesis, University of Hull. 418 pp. https:// hydra.hull.ac.uk/resources/hull:1002

Beyer K, Kochanowska D, Longshaw M, Feist SW, Gozlan RE (2005) A potential role for invasive sunbleak in the further dissemination of a non-native parasite. J Fish Biol 67:1730-1733

Beyer K, Gozlan RE, Copp GH (2010) Social network properties within a fish assemblage invaded by non-native sunbleak Leucaspius delineatus. Ecol Model 221:2118-2122

Britton JR, Gozlan RE (2013) How many founders for a biological invasion? Predicting introduction outcomes from propagule pressure. Ecology 94:2558-2566

Britton JR, Cucherousset J, Davies GD, Godard MJ, Copp GH (2010a) Non-native fishes and climate change: predicting species responses to warming temperatures in a temperate region. Freshw Biol 55:1130-1141

Britton JR, Davies GD, Harrod C (2010b) Trophic interactions and consequent impacts of the invasive fish Pseudorasbora parva in a native aquatic foodweb: a field investigation in the UK. Biol Invas 12:1533-1542

Britton JR, Ruiz-Navarro A, Verreycken H, Amat-Trigo F (2017) Trophic consequences of introduced species: Comparative impacts of increased interspecific versus intraspecific competitive interactions. Funct Ecol. https:// doi.org/10.1111/1365-2435.12978

Busst GM, Britton JR (2016) High variability in stable isotope diet-tissue discrimination factors of two omnivorous freshwater fishes in controlled ex situ conditions. J Exp Biol 219:1060-1068

Busst GM, Britton JR (2018) Tissue-specific turnover rates of the nitrogen stable isotope as functions of time and growth in a cyprinid fish. Hydrobiologia 805:49-60

Busst G, Bašić T, Britton JR (2015) Stable isotope signatures and trophic-step fractionation factors of fish tissues collected as non-lethal surrogates of dorsal muscle. Rapid Commun Mass Spectrom 29:1535-1544

Collier KJ, Leathwick JR, Rowe DK (2017) Assessing vulnerability of New Zealand lakes to loss of conservation value from invasive fish impacts. Aquat Conserv Mar Freshw Ecosyst 27:534-546

Copp GH (2008) Putting multi-dimensionality back into niche breadth: diel vs. day-only niche separation in stream fishes. Fund Appl Limnol 170:273-280

Copp GH, Stakènas S, Davison PI (2006) The incidence of nonnative fishes in water courses: example of the United Kingdom. Aquat Invas 1:72-75

Copp GH, Templeton M, Gozlan RE (2007) Propagule pressure and the invasion risks of non-native freshwater fishes in Europe: a case study of England. J Fish Biol 71(Suppl D):148-159

Copp GH, Vilizzi L, Mumford JD, Fenwick GV, Godard MJ, Gozlan RE (2009) Calibration of FISK, an invasive-ness screening tool for non-native freshwater fishes. Risk Analy 29:457-467
Copp GH, Russell IC, Peeler EJ et al (2016) European Nonnative Species in Aquaculture Risk Analysis Scheme-a summary of assessment protocols and decision support tools for use of alien species in aquaculture. Fish Manag Eco 23:1-11

Copp GH, Britton JR, Guo Z, Edmonds-Brown VR, Pegg J, Vilizzi L, Davison PI (2017) Trophic consequences of nonnative pumpkinseed Lepomis gibbosus for native fishes on pond fishes. Biol Invas 19:25-41

Cornell University Stable Isotope laboratory (2015) Preparation guidelines. www.cobsil.com/iso_main_preparation_ guidlines.php. Accessed 22 May 15

Cucherousset J, Boulêtreau S, Martino A, Roussel JM, Santoul F (2012) Using stable isotope analyses to determine the ecological effects of non-native fishes. Fish Manag Ecol 19:111-119

Davies B, Biggs J, Williams P, Whitfield M, Nicolet P, Sear D, Bray S, Maund S (2008) Comparative biodiversity of aquatic habitats in the European agricultural landscape. Agricul Ecosyst Environ 125:1-8

Davies ZG, Fuller RA, Loram A, Irvine KN, Sims V, Gaston KJ (2009) A national scale inventory of resource provision for biodiversity within domestic gardens. Biol Conserv 142:761-771

Davies GD, Gozlan RE, Britton JR (2013) Can accidental introductions of non-native species be prevented by fish stocking audits? Aquat Conserv Mar Freshw Ecosyst 23:66-373

Farr-Cox F, Leonard S, Wheeler AC (1996) The status of the recently introduced fish Leucaspius delineatus (Cyprinidae) in Great Britain. Fish Manag Ecol 3:193-199

Fobert E, Fox MG, Ridgway M, Copp GH (2011) Heated competition: How climate change will affect competing non-native pumpkinseed and Eurasian perch in the U.K. J Fish Biol 79:1592-1607

Fobert E, Zięba G, Vilizzi L, Godard MJ, Fox MG, Stakènas S, Copp GH (2013) Predicting non-native fish dispersal under conditions of climate change: case study in England of dispersal and establishment of pumpkinseed Lepomis gibbosus in a floodplain pond. Ecol Freshw Fish 22:106-116

Fox J, Weisberg S (2011) An $\{\mathrm{R}\}$ Companion to applied regression, 2nd ed. Sage, Thousand Oaks. http://socserv. socsci.mcmaster.ca/jfox/Books/Companion

Gozlan RE (2008) Introduction of non-native freshwater fish: is it all bad? Fish Fish 9:106-115

Gozlan RE, Flower CJ, Pinder AC (2003a) Reproductive success in male sunbleak, a recent invasive fish species in the UK. J Fish Biol 63(Suppl. A):131-151

Gozlan RE, Pinder AC, Durand S, Bass JAB (2003b) Could the small size of Leucaspius delineatus be an ecological advantage in invading British watercourses? Folia Zool 52:99-108

Gozlan RE, Britton JR, Cowx IG, Copp GH (2010) Current knowledge on non-native freshwater fish introductions. J Fish Biol 76:751-786

Griffen BD, Guy T, Buck JC (2008) Inhibition between invasives: a newly introduced predator moderates the impacts of a previously established invasive predator. J Anim Ecol $77: 32-40$ 
Hickley P, Chare S (2004) Fisheries for non-native species in England and Wales: angling or the environment? Fish Manag Ecol 11:203-212

Hothorn T, Bretz F, Westfall P (2008) Simultaneous inference in general parametric models. Biom J 50:346-363

Hyslop EJ (1980) Stomach contents analysis-a review of methods and their application. J Fish Biol 17:411-429

Jackson MC, Britton JR (2014) Divergence in the trophic niche of sympatric freshwater invaders. Biol Invas 16:1095-1103

Jackson AL, Inger R, Parnell AC, Bearhop S (2011) Comparing isotopic niche widths among and within communities: Bayesian analysis of stable isotope data. J Anim Ecol 80:595-602

Jackson MC, Donohue I, Jackson AL, Britton JR, Harper DM, Grey J (2012) Population level metrics of trophic structure based on stable isotopes and their application using invasion ecology. PLoS ONE 7:e31757

Jackson MC, Britton JR, Cucherousset J, Guo Z, Stakenas S, Gozlan RE, Roussel J-M, Copp GH (2016) Do non-native pumpkinseed Lepomis gibbosus affect the growth, diet and trophic niche breadth of native brown trout Salmo trutta? Hydrobiologia 772:63-75

Klop-Toker K, Valdez J, Stockwell M, Clulow S, Clulow J, Mahony M (2017) Community level impacts of invasive mosquitofish may exacerbate the impact to a threatened amphibian. Aust Ecol. https://doi.org/10.1111/aec.12558

Korsu K, Huusko A, Muotka T (2009) Does the introduced brook trout (Salvelinus fontinalis) affect growth of the native brown trout (Salmo trutta)? Naturwissenschaften 96:347-353

Olsson K, Stenroth P, Nyström P, Granéli W (2009) Invasions and niche width: does niche width of an introduced crayfish differ from a native crayfish? Freshw Biol 54:1731-1740

Persson L, Greenberg LA (1990) Juvenile competitive bottlenecks: the perch (Perca fluviatilis)-roach (Rutilus rutilus) interaction. Ecology 7:44-56

Pinder AC, Gozlan RE (2003) Sunbleak and topmouth gudgeon-two new additions to Britain's freshwater fishes. Brit Wildl 15:77-83

Pitcher TJ (ed) (1986) Functions of shoaling behaviour in teleosts. In: The behaviour of teleost fishes (pp. 294-337). Springer, Berlin

Pollux BJA, Korosi A, Verberk WCEP, Pollux PMJ, Velde VDG (2006) Reproduction, growth, and migration of fishes in a regulated lowland tributary: potential recruitment to the river Meuse. Hydrobiologia 565:105-120

Post DM (2002) Using stable isotopes to estimate trophic position: models, methods, and assumptions. Ecology 83:703-718

Post DM, Layman CA, Arrington DA, Takimoto G, Quattrochi J, Montaña CG (2007) Getting to the fat of the matter: models, methods and assumptions for dealing with lipids in stable isotope analyses. Oecologia 152:179-189

R Development Core Team (2010) R: a language and environment for statistical computing. R Foundation for Statistical Computing, Vienna, Austria. www.R-project.org
Rahel FJ, Olden JD (2008) Assessing the effects of climate change on aquatic invasive species. Conserv Biol 22:521-533

Ruiz-Navarro A, Gillingham PK, Britton JR (2016) Shifts in the climate space of temperate cyprinid fishes due to climate change are coupled with altered body sizes and growth rates. Global Change Biol 22:3221-3232

Shea K, Chesson P (2002) Community ecology theory as a framework for biological invasions. Trend Ecol Evol 17:170-176

Spivak AC, Vanni MJ, Mette EM (2011) Moving on up: can results from simple aquatic mesocosm experiments be applied across broad spatial scales? Freshwat Biol 56:279-291

Tarkan AS, Gaygusuz O, Godard MJ, Copp GH (2011) Densitydependent basis of long-term growth patterns in a ponddwelling population of crucian carp Carassius carassius. Fish Manag Ecol 18:375-383

Thomas SM, Crowther TW (2015) Predicting rates of isotopic turnover across the animal kingdom: a synthesis of existing data. J Anim Ecol 84:861-870

Thomson D (2004) Competitive interactions between the invasive European honey bee and native bumble bees. Ecology $85: 458-470$

Tran TNQ, Jackson MC, Sheath D, Verreycken H, Britton JR (2015) Patterns of trophic niche divergence between invasive and native fishes in wild communities are predictable from mesocosm studies. J Anim Ecol 84:1071-1080

Tronquart NH, Mazeas L, Reuilly-Manenti L, Zahm A, Belliard J (2012) Fish fins as non-lethal surrogates for muscle tissues in freshwater food web studies using stable isotopes. Rapid Commun Mass Spectrom 26:1603-1608

Van der Putten WH, Macel M, Visser ME (2010) Predicting species distribution and abundance responses to climate change: why it is essential to include biotic interactions across trophic levels. Philos Trans R Soc B 365(1549):2025-2034

Van Valen L (1965) Morphological variation and width of ecological niche. Am Nat 99:377-390

Vilizzi L, Tarkan AS, Copp GH (2015) Experimental evidence from causal criteria analysis for the effects of common carp Cyprinus carpio on freshwater ecosystems: a global perspective. Rev Fish Fish 23:253-290

WCMC (1996) Leucaspius delineatus. In: IUCN 2007. 2007 IUCN. Red list of threatened species, www.iucnredlist.org

Zięba G, Copp GH, Davies GD, Stebbing PD, Wesley KJ, Britton JR (2010) Recent releases and dispersal of nonnative fishes in England and Wales, with emphasis on sunbleak Leucaspius delineatus. Aquat Invas 5:155-161

Zięba G, Fox MG, Copp GH (2015) How will climate change affect non-native pumpkinseed Lepomis gibbosus in the U.K.? PLoS ONE 10:e0135482

Zuur AF, Ieno EN, Walker NJ, Saveliev AA, Smith GM (2009) Mixed effects models and extensions in ecology with R. Springer, New York 